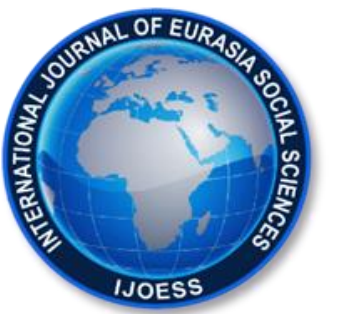

International Journal of Eurasia Social Sciences

Vol: 10, Issue: 37, pp. (849-862).

Research Article

Received: 27.05.2019 Accepted: 18.09.2019

\title{
AN EXAMINATION OF THE THESIS PREPARED FOR THE PRESCHOOL PERIOD BETWEEN THE YEARS 2010-2018
}

\author{
Oğuz Serdar KESiCiOĞLU \\ Associate Prof, Giresun University, kesiciogluserdar@gmail.com \\ ORCID:0000-0003-1176-1887 \\ Binnur Yıldırım HACIBBRAHIMOĞLU \\ Assistant Prof, Giresun University, binnury@gmail.com \\ ORCID: 0000-0002-6471-6054
}

\begin{abstract}
The research aimed to reveal through classification the graduate thesis written in the field of preschool education between the years of 2010-2018. This study was qualitative research, and the data were collected through the document examination method. The sampling for the research was determined with criterion sampling, a purposeful sampling strategy. Based on this, a total of 984 graduate thesis were examined with 787 master's thesis, 120 doctoral thesis, and 27 Medical/Dentistry thesis, that were written in the field of preschool education. In line with the specified criteria, the full texts of the thesis were recorded and studied based on the subheadings determined in the scope of the research. Frequency was utilized in the analysis of the data. It was determined as a result of the research that there was an increase in the number of graduate thesis in 2015 and afterwards and that this increase was especially prevalent in the master's field. The research determined that, with regard to types of research, a quantitative research method and experimental and survey research models were used more frequently. According to the results of the research, it is recommended that research groups aimed at the field of preschool education in Turkey be diversified and that different research models be used.
\end{abstract}

Keywords: preschool education, graduate education, doctorate, thesis 


\section{INTRODUCTION}

Preschool education is an important step of education whose application around the world has become quite widespread and whose importance is becoming more understood. Preschool is the first step of education for a child after life at home, and it contains various definitions based on perspective. A broad definition can be made as the educational process that lasts from birth until the age of six (Gordon \& Browne, 2011) or, by Ojala (1993), as an interactive process that includes all the developments of children aged zero-six in line with a certain goal in home and school life. In Turkey, preschool education is defined in the 14th National Education Council as an educational process that supports all fields of the development of children aged "0-72" months, that provides stimulation and environmental opportunities that are rich and suit their individual characteristics, that best guides the children in line with the cultural values of society and prepares them for primary school, and that is found within the integrity of foundational education (Ministry of National Education-MoNE, 1993). With the latest updates, preschool education has not entered into the age of mandatory primary education as optional but was explained as the education of children who are 36 months old and younger than 66 months (MoNE, 2018).

Starting from birth, early childhood is specified as a significant and critical period for the development of emotional, behavioral, and cognitive bases, and the physical, cognitive, emotional, and social development that is formed in this process constitutes the foundation for the development of the individual in years to come (Trawick-Smith, 2014; Woolfolk \& Perry, 2012). The experiences and interventions a child experiences affect the physical and mental health of the child and the development of their behavioral, social, and emotional skills as well as helping to prevent inequality originating from the socioeconomic status and risks in which the children find themselves and to create equality of opportunity (Mother Child Education Foundation, 2017). Loeb, Bridges, Fuller, Rumberger, and Bassok (2007) report that preschool education is positively influential in the cognitive development and school preparedness of young children coming from a low socioeconomic environment. It has been revealed in the findings acquired from long-term studies that a child is influenced by environmental factors and that, accordingly, preschool education services are important (Kağıtçıbaşı, 1991; Barnett, 1995; Openheim \& MacGregor, 2002; Reynolds \& Ou, 2004). This is why both the field of education and various fields such as developmental psychology, cultural psychology, and history give weight to studies over preschool education (Roopnarine \& Johnson, 2005).

Grasping the importance of preschool education reflects on the institutions cultivating preschool teachers. It is seen in Turkey that a significant part of the studies aimed at rearing preschool teachers after the 1960s were conducted with the department of child development. The department was founded with the name "Child Development and Education" in the constitution of the Hacettepe University Faculty of Health Sciences Home Economics Graduate School in 1968 (Dağlıoğlu, 2007; Koçak and Alakoç Pirpir, 2015). Kindergarten teaching associate's degree programs were opened at some universities in 1979. Kindergarten teaching programs were located separately within faculties of education in 1991-92, and the duration of the educational programs was extended up to four years (Dağlığlu, 2007). At many universities today, the preschool education department 
provides at both the undergraduate and graduate level. As a result of this situation, an increase was seen in the number of studies conducted in the field of preschool education. Particularly as a result of graduate education are many thesis being presented to the body of literature. Thesis referred to as scientific research reports (Tavşancıl vd., 2010) provide significant contributions to the area in which they are conducted because they are studies evaluated and approved by a scientific council and they deal in detail with a certain topic scientifically (Evrekli, İnel, Deniş and Günay Balım, 2011).

It was determined when examining the studies aimed at the field of the detailed analysis of thesis in the field preschool education in Turkey that thesis examination studies that take certain fields subject to certain fields are conducted in areas including drama (Can Yaşar and Aral, 2011), games (Kaytez and Durualp, 2014), social skills (Gülay Ogelman, 2014), sciences (Avar and Ilıcan, 2018; Gülay Ogelman and Güngör, 2015), inclusion (Taştepe, Öztürk Serter, Yurdakul, Altıntaş Taygur and Bütün Ayhan, 2016), and creativity (Karlıdağ, 2018). Additionally, it is seen in the examination of the existing body of literature that the number of studies in which all thesis that are beyond the scope of a certain subject are examined is low (Abalı Öztürk and Demir, 2018; Altun, Şendil and Şahin, 2011; Durukan, Atalay and Şen, 2015; Şahin and Bartan, 2017) and that these studies cover different intervals. This is why the collection of the thesis conducted in Turkey and based on preschool education in a single study and the presentation of the necessary information regarding these thesis will help people interested in the field of preschool education reach access the necessary information. This study also is deemed important in terms of presenting guiding information on the topic of aspects that remain insufficient on yet undiscussed or unresearched topics for researchers. Therefore, this study aims to review graduate thesis studies that were carried out in the field of preschool education in Turkey.

\section{METHOD}

Information has been provided in this section with regard to the model, population, sampling, data collection, data analysis, validity, and reliability for the research.

\section{Research Model}

This research was conducted for the purpose of revealing through classification the graduate thesis written in the field of preschool education in Turkey, and it is a descriptive study aimed at determining the existing situation in which qualitative research methods are implemented. Qualitative research is a method of research utilized to access information about situations about which there is not fully formed knowledge or that are difficult to evaluate with quantitative measurements, and also to gain a new perspective on a situation about which we have knowledge (Corbin and Strauss, 2007). This research was conducted to reveal the profiles of faculty members in Preschool Education Departments in Turkey and to reveal subject contents, and it is a descriptive-survey model study aimed at determining the existing situation in which qualitative research methods are implemented. Because survey models are a model suitable for research that aims to describe in its existing form a current or past situation (Karasar, 2005). 


\section{Materials}

The research used a criterion sampling that enables working with situations that meet a series of predetermined criteria from purposeful sampling methods in the determination of the sampling (Yıldırım and Şimşek, 2011). The research determines the express thesis' publication to access in the Higher Education Institution National Thesis Center and the keyword "preschool" as criteria. The sampling of the research comprises a total of 984 graduate thesis were examined, with 787 master's thesis, 120 doctoral thesis, and 27 Medical/Dentistry thesis, that were written in the field of preschool education between January 1, 2008 and September 1, 2018. A general evaluation of the Medical/Dentistry thesis was used in (Table 1 and Table 2) and other evaluations were not used in (Table 3, Table 4, and Table 5).

\section{Collection of Data}

A document evaluation, a qualitative research method, was used to gather the research data. A document examination encompasses an analysis of the written materials that contain information about the case or cases targeted in the research. Document examination is a data-collection tool that is essential for almost all research (Metin, 2012; as cited in Yenilmez and Sölpük, 2014). A document examination encompasses an analysis of the written materials that contain information about the case or cases targeted in the research. Document examination can be used with other data-collection methods, just as it can be used on its own (Yıldırım and Şimşek, 2011). Document examination is related to the status of some cases at a certain time or the development in a certain period of time. An important purpose is served with gaining the information obtained with this state for the body of literary field. Records, reports, printed forms, letters, autobiographies, personal journals, essays, academic studies, books, publications, catalogs, films, pictures, or caricatures can be used in the document examination as a data source. The most important situation at this stage is checking that the documents that the researcher obtained are healthy and reliable (Best and Kahn, 2006). The document examination can be conducted in five stages, and these stages are monitored in this study: (1) document access, (2) checking originality, (3) understanding the documents, (4) analyzing the data, and (5) using the data (Metin, 2012; as cited in Yenilmez and Sölpük, 2014).

The documents used in the study were open for access in the Higher Education Council Electronic Thesis Center, were prepared in the field of preschool education, and were obtained using graduate thesis. A survey was conducted by writing the keyword "Preschool" in the "Enter the Survey Term" on the main page of the thesis center between the dates of June 1, 2018 and September 1, 2018. During the collection of data in the study, the researcher utilized the method section of the thesis in order to obtain the necessary information.

\section{Data Analysis}

For the purpose of examining the data obtained from the evaluation of the research data in a more detailed manner, a "content analysis", a method used in qualitative data analysis, was used, and the data were analyzed by individually coding for each teacher and family. The content analysis is a method with wide applicability in 
educational research. The fundamental process performed in the content analysis is to bring together the data that resemble each other within certain concepts and themes and to interpret these by organizing them in a format that the reader can understand. A content analysis commonly used in qualitative research is an analysis research method that numerically determines some of the characteristics of the text, and it works as a bridge between the qualitative analysis and statistical results of the text (Bauer, 2003; Karasar, 2005; Fraenkel and Wallen, 2006; Yıldırım and Şimşek, 2011). The objective of the research was taken into consideration while coding in the study, and codes were created in this respect. The codes were created with an open coding method. In this respect, the codings were interpreted after being primarily tabulated. In the creation of themes (categorization), either themes previously developed by others are taken or, when this had not been previously done, a new system of themes can be developed (Bilgin, 2006). The distributions of the grouped data were presented in the form of tables and graphics and interpreted. The data in this study were examined based on publication date, study type, research group, research method, and research model while being analyzed, and, by grouping them under five different subject headings, they were categorized and presented in the relevant tables.

\section{Validity and Reliability of the Research}

In order to ensure the internal and external validity and reliability of the research, the steps laid out below were followed (Bağcı, 2012; İşçi, 2013).

In order to ensure the internal validity of the study: (i) the data obtained from the study were presented in the findings section, and information related to this situation were revealed and underwent interpretation. (ii) In order to ensure the consistency of the findings, the consistency amongst themselves of the themes for which categories are created are evaluated with consideration of the internal homogenic and external homogenic criteria. In order to ensure the external validity of the study: $(i)$ operations in the processes of the design, sampling, data-collection tool, and data analysis in the methods section of the study were included in detail. (ii) The thesis records and analyses transferred to a computer were preserved for potential confirmation in the future.

In order to ensure the internal reliability of the study: (i) the data analysis was given directly without making any preliminary interpretations. (ii) The codings in the data analysis process were redone by another researcher. In order to ensure the external reliability of the study: (i) situation worked and methods used in the study were presented in detail in the relevant sections of the study to help researchers who will conduct similar studies in the future while constructing study designs. (ii) Detailed explanations have been provided with regard to data collection and analysis methods. (iii) The data-collection tool used in the research will be stored in order to be able to present, when necessary, the thesis and records transferred to a computer, codings made in the analysis stage, and the notes taken throughout the study. 


\section{FINDINGS}

Information was provided in this section regarding the date, the examined graduate thesis were published, study type, research group, research method, and research model.

Table 1. Distribution of the Examined Thesis by Year

\begin{tabular}{cc}
\hline Year & $\mathbf{n}$ \\
\hline 2008 & 46 \\
\hline 2009 & 56 \\
\hline 2010 & 67 \\
\hline 2011 & 64 \\
\hline 2012 & 70 \\
\hline 2013 & 81 \\
\hline 2014 & 87 \\
\hline 2015 & 142 \\
\hline 2016 & 132 \\
\hline 2017 & 148 \\
\hline 2018 & 41 \\
\hline TOTAL & 934
\end{tabular}

When studying Table 1, it is seen that the most thesis were prepared in 2017 ( $n=149), 2015$ ( $n=142)$, and 2016 $(n=132)$. A decrease is seen in 2018. This situation can be explained with the conclusion of the data-collection process in September 2018.

Table 2. Distribution of the Studies Examined by Type of Study

\begin{tabular}{|c|c|c|}
\hline YEAR & Type of Study & $\mathrm{n}$ \\
\hline \multirow[t]{3}{*}{2008} & Master's & 41 \\
\hline & Doctorate & 5 \\
\hline & Medical/Dentistry & - \\
\hline \multirow[t]{3}{*}{2009} & Master's & 47 \\
\hline & Doctorate & 8 \\
\hline & Medical/Dentistry & 1 \\
\hline \multirow[t]{3}{*}{2010} & Master's & 57 \\
\hline & Doctorate & 6 \\
\hline & Medical/Dentistry & 4 \\
\hline \multirow[t]{3}{*}{2011} & Master's & 52 \\
\hline & Doctorate & 9 \\
\hline & Medical/Dentistry & 3 \\
\hline \multirow[t]{3}{*}{2012} & Master's & 59 \\
\hline & Doctorate & 11 \\
\hline & Medical/Dentistry & - \\
\hline \multirow[t]{3}{*}{2013} & Master's & 69 \\
\hline & Doctorate & 11 \\
\hline & Medical/Dentistry & 1 \\
\hline \multirow[t]{3}{*}{2014} & Master's & 74 \\
\hline & Doctorate & 11 \\
\hline & Medical/Dentistry & 2 \\
\hline \multirow[t]{3}{*}{2015} & Master's & 120 \\
\hline & Doctorate & 19 \\
\hline & Medical/Dentistry & 3 \\
\hline
\end{tabular}




\begin{tabular}{ccc}
\hline \multirow{2}{*}{2016} & Master's & 110 \\
\cline { 2 - 3 } & Doctorate & 19 \\
\cline { 2 - 3 } & Medical/Dentistry & 3 \\
\cline { 2 - 3 } & Master's & 122 \\
\cline { 2 - 3 } & Doctorate & 18 \\
\hline \multirow{2}{*}{2018} & Medical/Dentistry & 8 \\
\hline & Master's & 36 \\
\cline { 2 - 3 } & Doctorate & 3 \\
\cline { 2 - 3 } & Medical/Dentistry & \\
\cline { 2 - 3 } & &
\end{tabular}

It was determined when examining Table 2 that the most graduate thesis were written in 2017 ( $n=122), 2015$ $(n=120)$, and $2016(n=110)$, and the most doctoral thesis were written in $2016(n=19), 2015$ (n=19), and 2017 $(n=18)$.

Table 3. Distribution of the Examined Thesis by Research Group

\begin{tabular}{|c|c|c|c|c|c|c|c|c|c|c|c|c|c|c|c|c|}
\hline & \multicolumn{2}{|c|}{ Children } & \multicolumn{2}{|c|}{ Teachers } & \multicolumn{2}{|c|}{$\begin{array}{c}\text { Administra } \\
\text { tors/Superi } \\
\text { ntendents }\end{array}$} & \multicolumn{2}{|c|}{ Families } & \multicolumn{2}{|c|}{$\begin{array}{l}\text { Teaching } \\
\text { Candidates }\end{array}$} & \multicolumn{2}{|c|}{$\begin{array}{l}\text { Physical } \\
\text { Frame }\end{array}$} & \multicolumn{2}{|c|}{$\begin{array}{c}\text { Literature } \\
\text { Review }\end{array}$} & \multicolumn{2}{|c|}{ Total } \\
\hline & 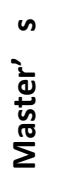 & 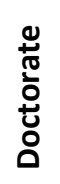 & 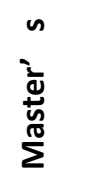 & 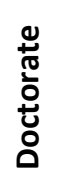 & $\begin{array}{l}n \\
\frac{2}{d} \\
\stackrel{n}{n} \\
\Sigma \\
\Sigma\end{array}$ & 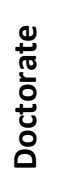 & 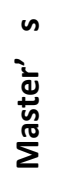 & 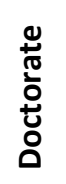 & 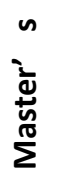 & 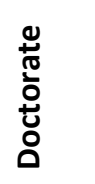 & 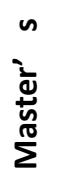 & 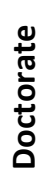 & $\begin{array}{l}n \\
\frac{1}{d} \\
\stackrel{n}{n} \\
\frac{0}{0} \\
\Sigma\end{array}$ & $\begin{array}{l}\stackrel{0}{0} \\
\frac{\pi}{0} \\
\stackrel{0}{0} \\
0\end{array}$ & $\begin{array}{l}n \\
\frac{2}{d} \\
\frac{n}{n} \\
\frac{\pi}{0} \\
\Sigma\end{array}$ & 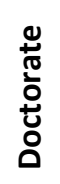 \\
\hline 2008 & 19 & 3 & 15 & - & 4 & - & 8 & 1 & 1 & 1 & 1 & - & 1 & - & 49 & 5 \\
\hline 2009 & 20 & 7 & 18 & 1 & 1 & - & 4 & - & 5 & - & 2 & - & 4 & - & 54 & 8 \\
\hline 2010 & 25 & 4 & 23 & 2 & 2 & 1 & 7 & 1 & 4 & - & - & - & 2 & - & 63 & 8 \\
\hline 2011 & 22 & 4 & 21 & 5 & 5 & - & 6 & 1 & 5 & - & 1 & - & 3 & - & 63 & 10 \\
\hline 2012 & 36 & 4 & 13 & 5 & 1 & 1 & 3 & 2 & 1 & 1 & 2 & - & 7 & 2 & 63 & 15 \\
\hline 2013 & 30 & 6 & 29 & 3 & 4 & - & 6 & 1 & 3 & - & 1 & 1 & 2 & 1 & 75 & 12 \\
\hline 2014 & 26 & 6 & 30 & 3 & 12 & - & 10 & 2 & 4 & - & 1 & - & 6 & - & 83 & 11 \\
\hline 2015 & 64 & 15 & 33 & 4 & 11 & - & 23 & 2 & 6 & 2 & 1 & - & 8 & - & 146 & 23 \\
\hline 2016 & 55 & 13 & 41 & 5 & 6 & - & 9 & 1 & 6 & 2 & 1 & - & 8 & - & 126 & 21 \\
\hline 2017 & 72 & 15 & 36 & 3 & 6 & - & 16 & - & 7 & 1 & 4 & - & 8 & - & 149 & 19 \\
\hline 2018 & 24 & 2 & 8 & 1 & 1 & - & 7 & - & 1 & - & 2 & - & 2 & - & 45 & 3 \\
\hline Total & 393 & 79 & 267 & 32 & 53 & 2 & 99 & 11 & 43 & 7 & 16 & 1 & 51 & 3 & & \\
\hline
\end{tabular}

When examining Table 3, it is seen that, in the master's thesis, most frequently children $(n=393)$ and teachers $(n=267)$ and least frequently physical environment $(n=16)$ and teaching candidates $(n=43)$ constituted the research groups, while in the doctoral thesis, most frequently children $(n=79)$ and teachers $(n=32)$ and least frequently physical environment $(n=1)$ and administrators/superintendents $(n=2)$ constitute the working group. 
Table 4. Distribution of the Examined Thesis by Research Method

\begin{tabular}{|c|c|c|c|c|c|c|c|c|}
\hline \multirow[b]{2}{*}{ YEAR } & \multicolumn{2}{|c|}{ Quantitative } & \multicolumn{2}{|c|}{ Qualitative } & \multicolumn{2}{|c|}{ Mixed } & \multicolumn{2}{|c|}{ Total } \\
\hline & $\begin{array}{l}n \\
\frac{1}{d} \\
\frac{n}{n} \\
\tilde{n} \\
\Sigma\end{array}$ & 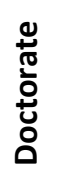 & \begin{tabular}{l}
$n$ \\
$\frac{1}{d}$ \\
\multirow{n}{n}{} \\
$\Sigma$ \\
$\Sigma$
\end{tabular} & 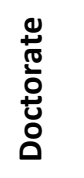 & 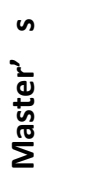 & 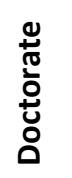 & 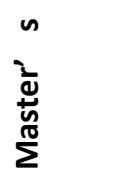 & 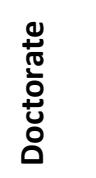 \\
\hline 2008 & 35 & 4 & 5 & 1 & 1 & - & 41 & 5 \\
\hline 2009 & 36 & 6 & 10 & 2 & 1 & - & 48 & 8 \\
\hline 2010 & 47 & 4 & 6 & 2 & 4 & - & 57 & 6 \\
\hline 2011 & 41 & 4 & 9 & 5 & 2 & - & 52 & 9 \\
\hline 2012 & 38 & 9 & 17 & 1 & 4 & 1 & 59 & 11 \\
\hline 2013 & 52 & 6 & 13 & 2 & 4 & 3 & 69 & 11 \\
\hline 2014 & 51 & 7 & 18 & 2 & 5 & 2 & 74 & 11 \\
\hline 2015 & 92 & 15 & 24 & 4 & 4 & - & 120 & 19 \\
\hline 2016 & 86 & 13 & 22 & 2 & 2 & 4 & 110 & 19 \\
\hline 2017 & 86 & 12 & 28 & 1 & 8 & 5 & 122 & 18 \\
\hline 2018 & 26 & 2 & 9 & 1 & 1 & - & 36 & 3 \\
\hline
\end{tabular}

It is seen when studying Table 4 that in the master's thesis, quantitative research was most conducted in 2015 ( $n=92)$, and 2016 and 2017 ( $n=86)$, qualitative research was most conducted in 2017 ( $n=28), 2015$ ( $n=25)$, and $2016(n=22)$, and mixed research was most conducted in $2017(n=8)$ and $2014(n=5)$; and in the doctoral thesis, quantitative research was conducted most in $2015(n=15), 2016(n=13)$, and $2017(n=12)$, qualitative research was most conducted in $2011(n=5)$ and $2015(n=4)$, and mixed research was most conducted in $2017(n=5)$, $2016(n=4)$, and $2013(n=3)$.

Table 5. Distribution of the Examined These by Research Model

\begin{tabular}{|c|c|c|c|c|c|c|c|c|}
\hline & \multicolumn{2}{|c|}{ Experimental } & \multicolumn{2}{|c|}{ Survey } & \multicolumn{2}{|c|}{$\begin{array}{c}\text { Document } \\
\text { examination }\end{array}$} & \multicolumn{2}{|c|}{ Total } \\
\hline & 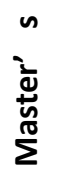 & 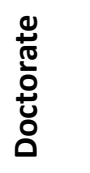 & 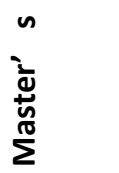 & 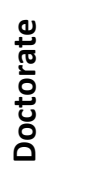 & 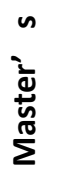 & 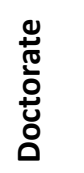 & 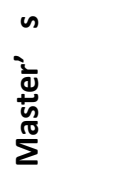 & 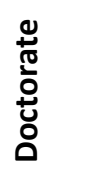 \\
\hline 2008 & 3 & 1 & 37 & 4 & 1 & - & 41 & 5 \\
\hline 2009 & 10 & 5 & 32 & 2 & 5 & 1 & 47 & 8 \\
\hline 2010 & 8 & 3 & 47 & 3 & 2 & - & 57 & 6 \\
\hline 2011 & 5 & 3 & 44 & 6 & 3 & - & 52 & 9 \\
\hline 2012 & 11 & 5 & 39 & 6 & 9 & - & 59 & 11 \\
\hline 2013 & 17 & 2 & 51 & 9 & 1 & - & 69 & 11 \\
\hline 2014 & 9 & 4 & 61 & 7 & 4 & - & 74 & 11 \\
\hline 2015 & 19 & 11 & 92 & 8 & 9 & - & 120 & 19 \\
\hline 2016 & 19 & 9 & 81 & 10 & 10 & - & 110 & 19 \\
\hline 2017 & 27 & 11 & 84 & 7 & 11 & - & 122 & 18 \\
\hline 2018 & 6 & 1 & 25 & 2 & 5 & - & 36 & 3 \\
\hline
\end{tabular}

It is seen when studying Table 5 that in master's thesis, the most experimental research was conducted in 2017 $(n=27)$ and 2015 and $2016(n=19)$, the most survey research was conducted in $2015(n=92), 2017(n=84)$, and $2016(n=81)$, and the most document examination research was conducted in $2017(n=11), 2016(n=10)$, and 
2015 ( $n=9)$; and in doctoral thesis, the most experimental research was conducted in 2015, 2017 ( $n=11)$ and $2016(n=9)$, the most survey research was conducted in $2016(n=10), 2013(n=9)$, and $2015(n=8)$, and document examination research was only conducted in $2009(n=1)$.

\section{DISCUSSION}

This research aimed to examine the thesis prepared in the field of preschool education between 2008-2018. When examining the results obtained from the study, it was first determined that the year in which the most thesis were written in the past 10 years was 2017, and that while the findings between 2008 and 2015 exhibit a certain level of progression, there is a significant increase in the number of thesis written, particularly in 2015 and later. This acquired finding varies from other studies in the body of literature (Abalı Öztürk ve Demir, 2018; Altun, Şendil and Şahin, 2011; Durukan, Atalay and Şen, 2015; Şahin and Bartan, 2017). The distribution of the conducted thesis by year exhibits a constant increase in this study. In the studies by Abalı Öztürk and Demir (2018); Altun, Şendil and Şahin (2011); Durukan, Atalay, and Şen (2015); and Şahin and Bartan (2017), it was reported that there was an irregularity in the form of increase or decrease in the distribution of thesis by year. A report published by Mother Child Education Foundation (2017), explained that preschool education in Turkey is primarily conducted by public institutions connected to the Ministry of National Education and that the existing services constitute half-day educational services aimed at children over the age of five. The report specifies that, at the same time, incentives were created to increase attendance in preschool education services in the private sector. The strategies of the propagation of preschool education, the diversification of service presentation models that will increase attendance in preschool education, supporting the access to preschool education by financially restricted areas and regions, and making arrangements that will decrease the costs falling on families in preschool education were included in the MoNE 2015-2019 Strategy Plan. The development of schooling in preschool education has been presented as a primary field. In the 2017-2019 Medium-Term Program published by the Ministry of Development also included the goals of incrementally making preschool education mandatory by 2019. Based on this, the Ministry of National Education explained that as of the 2017-2018 academic year it has initiated pilot studies in some provinces (TEDMEM, 2017). This situation in the country increases the need for preschool teachers. Therefore, the preschool education department at the private and state schools of Turkey both meets the needs of the teacher and exhibits development at the undergraduate and graduate level. The increase in the distribution of the conducted thesis by year can be interpreted as a result of this situation. When the types of thesis are examined at the same time in the study, it is seen that the most master's and doctoral thesis were written in 2017, 2016, and 2015. The conditions for entry into doctoral education contain more aspects, and doctoral education requires more effort relative to the master's education process financially, in terms of time, and psychologically. These factors could be influential in the numerically fewer number of doctoral thesis compared with master's thesis.

The research findings tender that the master's and doctoral thesis studies are most conducted over groups of children and are least conducted, in master's thesis, in physical settings and, in doctoral thesis, over physical settings and administrators/superintendents. However, the acquired results demonstrate that although 
physical environment and administrators are numerically the least frequent research groups, sufficient studies have not been conducted over teachers, teaching candidates, families, and the literature. Aral, Fındık Tanıyurdu, Yurteri Tiryaki, Sağlam, and Aysu (2015) obtained the finding in the thesis examination they conducted in the field of child development that the most studied research group was preschool children. Similarly, Şahin and Bartan (2017) and Abalı Öztürk and Demir (2018) obtained in their studies teachers and children as the most frequently studied groups. This result was determined in the thesis examination studies that are the subject of certain areas in the field of preschool education (Avar and llıcan, 2018; Karlıdağ, 2018). The fact that studies were most frequently conducted over children as the research group was an expected result. The fact that studies conducted in the field of preschool education over children and the output of child development becoming commonplace is deemed valuable in terms of the presenting important information to the field. Also, with regard to this finding, Karadağ's (2009) interpretation that researchers in Turkey could repeat the study previously conducted by changing the population or sampling of the research rather than turn to new and unique topics.

When examining the research methods used in the thesis in the study, it is seen that quantitative studies are generally more weighted. The numerical increase in the thesis written in 2015 and later directly reflect the research methods used in the thesis. It was seen in a vast majority of the master's thesis that, while quantitative research methods were adopted, fewer qualitative and mixed methods were included. This finding is consistent with the body of literature (Can Yaşar and Aral, 2011; Durukan, Atalay and Şen, 2015; Kaytez and Durualp, 2014; Şahin and Bartan, 2017). Along with the finding that the number of quantitative studies exhibiting a tendency towards research in the field of preschool education, it can be said that when the studies conducted in different disciplines (Aydın, Erdağ and Sarıer, 2010; Göktaş et al., 2012; Sözbilir and Kutlu, 2008; Şenyurt and Özer Özkan, 2017; Tavşancıl et al., 2010; Ulutaş and Ubuz, 2008) are interpreted, this tendency is not specific to one field but reflects the general situation in Turkey.

In the findings acquired based on the research model, it is seen that experimental and survey research in master's thesis are more often used and have exhibited an increase in recent years. In the doctoral thesis, the conclusion was reached that survey studies are generally more weighted. It was determined that the document examination model was handled at only one study at the doctoral level. In the survey studies, using numerical expressions, attempts can be made to work with a short-term, large group in order to be able to make generalizations and make progressive estimations (Glesne and Peskin, 1992). The document examination is a qualitative research method, and qualitative research is defined as an approach that uses an inductive approach and that emphasizes the descriptive data-collection technique in natural settings and the perspective of research subjects (Bogdan and Biklen, 2006). At the same time, it is reported in this method that the researcher referred to the details and examined the richness, depth, and complexity of any of the cases (Yıldırım and Şimşek, 2011). This is why it can be said that document examination studies are preferred because they require more time. 


\section{CONCLUSION AND RECOMMENDATIONS}

The research contains the master's and doctoral thesis written in Turkey in the field of preschool education between the years of 2010-2018. In the scope of the research, the thesis studies conducted in the field of preschool education exhibit increases and diversity as the years pass. In the specification of the studies, the criteria attempting to be presented in detail in the methods section were taken as a basis. These criteria at the same time constitute the limitations of the research. The research was conducted on the Higher Education Council Electronic Thesis Center. In this context, it can be said that the results in the distribution of the examined thesis by year were clearer and that, in order to increase the number of examined thesis, minimizing the restrictions or allowing the researchers to access the thesis is important in terms of increasing the researchers' access to resources and the quality of the studies conducted in the field. Only thesis were included in this study. Articles, presented reports, and books could also be handled in subsequent studies.

In line with the results of the research, it is thought that increasing the number of studies conducted with graduate students will bring contributions to the field. It was determined that children were chosen most often as the working group in the examined thesis. This is why it is recommended that working groups be formed that provide rich information with which children, teachers, and families can be discussed together in the thesis. At the point of approaching the research, it is recommended that weight be given to qualitative and mixed methods in terms of providing variety and detailed information to the field. At the same time, a bibliometric study could be conducted in which the bibliographic sections of thesis written in the field of preschool education are examined in detail.

\section{REFERENCES}

Abalı Öztürk, Y. \& Demir, M. K. (2018). An analysis of graduate thesis on early childhood education: The case of Turkey. International Electronic Journal of Elementary Education (IEJEE), 10 (5), 583-590.

Altun, D., Şendil, Ç. Ö. \& Şahin İ. T. (2011). Investigating the national dissertation and thesis database in the field of early childhood education in Turkey. Procedia Social and Behavioral Sciences, 12, 483- 492.

Aral, N., Fındık Tanrıbuyurdu, E., Yurteri Tiryaki, A., Sağlam, M. \& Aysu, B.(2015). Türkiye'de çocuk gelişimi alanındaki lisansüstü tezlerin incelenmesi. Ankara Sağık Hizmetleri Dergisi, 14(1), 7-16.

Avar, G. \& Ilıcan, S. (2018). Okul öncesi fen eğitimi alanında Türkiye'de yapılan lisansüstü tezlerin incelenmesi (2013-2017). Akademik Sosyal Araştırmalar Dergisi, 6 (71), 1-16.

Aydın, A. Erdağ, C. \& Sarıer, Y. (2010). A comparison of articles published in the field of educational administration in terms of topics, methodologies and results. Eurasian Journal of Educational Research, 39, 37-58.

Barnett, S. W. (1995). Long term effects of early childhood programs on cognitive and school outcomes. The Future of Children, 17, 69-8. 
Bağcı, Ş. (2012). Sınıf öğretmenliği lisansüstü tezlerinin karakteristik özellikleri: Tematik, metodolojik ve istatistiksel yönelimler. Yayımlanmamış yüksek lisans tezi, Eskişehir Osmangazi Üniversitesi Eğitim Bilimleri Enstitüsü, Eskişehir.

Bauer, Martin. W. (2003). Classical content analysis: A review. In M. W. Bauer \& G. Gaskell (Eds).

Qualitative researching with text, image and sound (pp.131). London: Sage Publication.

Best, J. W. \& Kahn, J. V. (2006). Research in Education (Tenth Edition.). Boston: PearsonEducation.

Bilgin, N. (2006). Sosyal Bilimlerde Içerik Analizi. Ankara: Siyasal.

Bogdan, R. C., \& Biklen, S. K. (2007). Qualitative Research for Education: An Introduction to Theories and Methods. Boston: Pearson A\&B.

Can Yaşar, M. \& Aral, N. (2011). Türkiye'de okul öncesinde drama alanında yapılan lisansüstü tezlerin incelenmesi. Mehmet Akif Ersoy Üniversitesi Eğitim Fakültesi Dergisi, 11(22), 70-90.

Corbin, J. M., \& Strauss, A. C. (2007). Basics of Qualitative Research:Techniques and Procedures for Developing Grounde Theory. Thousand Oaks, CA: Sage.

Dağlıoğlu, H.E. (2011). Okul öncesi öğretmeninin özellikleri ve okul öncesi eğitime öğretmen yetiştirme. G. Haktanır (Ed.), Okul öncesi eğitime giriş içinde (s.39-78). Ankara: Anı Yayıncılık.

Durukan, H., Atalay, Y. \& Şen, S. N. (2015). Türkiye'de 2000- 2014 yılları arasında okul öncesi eğitimi alanında yapılan yüksek lisans tezlerinin incelenmesi. Dicle Üniversitesi Ziya Gökalp Eğitim Fakültesi Dergisi, 26, 62-77.

Evrekli, E.,Inel, D., Deniş, H. \& Günay Balım, A. (2011). Fen eğitimi alanındaki lisansüstü tezlerdeki yöntemsel ve istatistiksel sorunlar. Illköğretim Online, 10(1), 206-218.

Fraenkel, J. R., \& Wallen, N. E. (2006). How to Design and Evaluate Research in Education ～(Sixth Edition.). New York: McGraw-Hill.

Glesne, C. \& Peskin, A. (1992). Becoming Qualitative Researchers: An Introduction. White Plains, NY: Longman.

Gordon, A. M. \& Williams Browne, K. (2004). Beginnings and Beyond: Foundation in Early Childhood Education. NY: Thomson Learning Delmar.

Göktaş, Y.,Hasançebi, F., Varışoğlu, B., Akçay, A., Bayrak, N., Baran, M. \& Sözbilir, M. (2012). Türkiye'deki eğitim araştırmalarında eğilimler: Bir içerik analizi. Kuram ve Uygulamada Eğitim Bilimleri, 12(1), 443-460.

Grotewell, P. G. \& Burton, Y. R. (2008). Early childhood Education: Issues and Developments. USA: New York.

Gülay Ogelman, H. \& Güngör, H. (2015). Türkiye'deki okul öncesi dönem çevre eğitimi çalışmalarının incelenmesi: 2000-2014 yılları arasındaki tezlerin ve makalelerin incelenmesi. Mustafa Kemal Üniversitesi Sosyal Bilimler Enstitüsü Dergisi, 12 (32),180-194.

Gülay Ogelman, H. (2014). Türkiye'deki okul öncesi dönem sosyal beceri araştırmaları: 2000-2013 yılları arasındaki tezlerin incelenmesi. KSÜ Sosyal Bilimler Dergisi, 11 (2), 41-65.

İşçi, S. (2013). Türkiye'de eğitim yönetimi alanında yapılmış lisansüstü tezlerin tematik, metodolojik ve istatistiksel açıdan incelenmesi. Yayımlanmamış yüksek lisans tezi. Eskişehir Osmangazi Üniversitesi Eğitim Bilimleri Enstitüsü, Eskişehir. 
Kağıtçıbaşı, Ç. (1991). The early enrichment project in Turkey. United Nations Children's Fund, New York: United Nations.

Karadağ, E. (2009). Eğitim bilimleri alanında yapılmış doktora tezlerinin tematik açıdan incelemesi. Ahi Evran Üniversitesi Eğitim Fakültesi Dergisi, 10(3), 75-87.

Karasar, N. (2005). Bilimsel Araştırma Yöntemleri. Ankara: Nobel Yayınevi.

Karlıdağ, İ. (2018). Türkiye'de okul öncesi eğitimde yaratıcılık alanında yapılan lisansüstü tezlerin incelenmesi. Social Sciences Studies Journal, 4(14), 456-462.

Kaytez, N. \& Durualp, E. (2014). Türkiye'de okul öncesinde oyun ile ilgili yapılan lisansüstü tezlerin incelenmesi. Uluslararası Türk Eğitim Bilimleri Dergisi, 2(2), 110-122.

Koçak, N. \& Alakoç Pirpir, D. (2012). Okul öncesi öğretmeni. N. Avcı ve M. Toran (Ed.). Okul öncesi eğitime giriş içinde (s. 77-103), Ankara: Eğiten Kitap

Loeb, S., Bridges, M., Fuller, B., Rumberger, R. \& Bassok, D. (2007). How much is too much? The influence of preschool centers on children's social and cognitive development. Economics of Education Review, 26 (1), 52-66.

Ministry of National Education-MoNE. (1993). XIV. Milli Eğitim Şurası, Raporlar, Görüşmeler, Kararlar. İstanbul, Türkiye: Milli Eğitim Basımevi.

Ministry of National Education-MoNE. (2018). Milli Eğitim İstatistikleri Örgün Eğitim 2016-2017. Retrieved from https://sgb.meb.gov.tr/meb_iys_dosyalar/2018_09/06123056_meb_istatistikleri_orgun_egitim_2017_2 018.pdf

Mother Child Education Foundation (2017). 2017 faaliyet raporu. Retrieved January 25, 2019, https://www.acev.org/biz-kimiz/faaliyet-raporlarimiz/

Ojala, M. (1993). Grounds and Challenges for Early Childhood Education. Finland: Helsinki

Oppennheim, J. \& MacGregor, T. (2002). The economics of education: Public benefits of high-quality preschool education for low-income children: Building communities for change. Retrieved December 25, 2009, fromhttp://www.aradvocates.org/childcare/Economics_of_Education.pdf.

Özenç, M. \& Özenç, E. G. (2013). Sınıf öğretmenleri ile yapılan lisansüstü eğitim tezlerinin yöntem bölümü açısından incelenmesi. Abant İzzet Baysal Üniversitesi Eğitim Fakültesi Dergisi, 13(1).

Reynolds, A. J. \& Ou, S. (2004). Alterable predictors of childwell-being in the Chicago longitudinal study. Children and Youth Services Review, 26. 1-14.

Roopnarine, J. L. \& Johnson, J. E. (2005). Approaches to Early Childhood Education. USA: Preface.

Seçer, D., Ay, D., Ozan, C. . \& Yılmaz, B. Y. (2014). Rehberlik ve psikolojik danışma alanındaki araştırma eğilimleri: Bir içerik analizi, Turkish Psychological Counseling and Guidance Journal, 5(41), 49-60.

Sözbilir, M. \& Kutlu, H. (2008). Development and current status of science education research in Turkey. Essays in Education, Special Issue, 1-22.

Şahin, G. \& Bartan, M. (2017). Okul öncesi eğitim alanında yapılan lisansüstü tezlerin incelenmesi. The Journal of Academic Social Science Studies, 60 , 69-84.

Şenyurt, S. \& Özer Özkan, Y. (2017). Eğitimde ölçme ve değerlendirme alanında yapılan yüksek lisans tezlerinin 
tematik ve metodolojik açıdan incelenmesi. Illköğretim Online, 16(2), 628-653.

Tavşancıl, E., Çokluk, Ö., Çıtak, G. G., Kezer, F., Yıldırım, Ö. Y., Bilican, S., Büyükturan, E.B., Şekercioğlu, G., Yalçın, N. Erdem, D. \& Özmen, D.T. (2010). Eğitim bilimleri enstitülerinde tamamlanmış lisansüstü tezlerin incelenmesi (2000-2008). Ankara Üniversitesi Bilimsel Araştırma Projesi Kesin Raporu.

Taştepe T., Öztürk Serter G., Yurdakul, Y., Altıntaş Taygur T., \& Bütün Ayhan, A. (2016). Türkiye'de okul öncesi dönemde kaynaştırma konusunda yapılan lisansüstü tezlerin incelenmesi. The Journal of Academic Social Science, (49), 501-514

Trawick-Smith, J. (2014). Early childhood development (6th ed.). Boston, MA: Pearson.

Ulutaş, F. \& Ubuz, B. (2008). Matematik eğitiminde araştırmalar ve eğilimler: 2000 ile 2006 yılları arası. ilköğretim Online, 7(3), 614-626.

Woolfolk, A., \& Perry, N. E. (2012). Child and Adolescent Development. Boston, MA: Pearson.

Yenilmez, K., Sölpük, N. (2014). Matematik dersi öğretim programı ile ilgili tezlerin incelenmesi (2004-2013). Eğitim ve Öğretim Araştırmaları Dergisi 3(2), 33:42.

Yıldııım, A., Şimşek H. (2011). Sosyal Bilimlerde Nitel Araştırma Yöntemleri (8. baskı). Ankara: Seçkin Yayıncılık. 